\title{
THE SUPREME COURT, THE COMMERCE CLAUSE AND COMMON LAW RULES
}

In the recent decision in Missouri Pacific Ry. Co. v. Larabee Flour Mills Co., ${ }^{1}$ the Supreme Court seems to me to have entirely forgotten, or to have ignored its own decision rendered only a few years before, after due deliberation. The circumstance is the more remarkable, in that in both instances the same judge delivered the opinions of the court.

The question involved related to a subject that is perhaps not yet entirely free from obscurity, the effect of the commerce clause of the Federal Constitution with reference to the application of merely common law rules. Now it is established that the existence of the power of Congress under such provision, precludes to an extent at least, even in the absence of exercise of such power, the exercise of any power of regulation under the authority of State legislation. ${ }^{2}$ But does the existence of such power in Congress likewise preclude the application (whether in the Federal or the State courts) of merely common law rules, to commerce within the scope of the commerce clause? To illustrate: Suppose a rule regulating the liability of a carrier in case of loss to be based on a State statute merely, and on that account inapplicable to commerce within the scope of the commerce clause. ${ }^{3}$ Suppose, however, such rule of liability to be purely a common law rule, is it not applicable to such commerce even if sought to be enforced in a State court? The artificiality of such distinction, if it exists, seems to me apparent from a consideration of what would be the effect of a statute merely declaratory of the common law. Regarding the rule declared as merely statutory, it would seem inapplicable to commerce within the scope of the commerce clause; regarding it as a common law rule, it would be applicable. Yet in both instances the practical effect seems precisely the same.

\footnotetext{
I 2II U. S., 6I2 (1909).

2 Of the numerous decisions in point, see for instance, Bowman $v$. Chicago \& Northwestern Ry. Co., 125 U. S., 465, 48I (I888).

3 See for instance, Central of Georgia $R y$. Co. v. Markley, Ig06 U. S., 194 (I905).

That if would be given the same effect, may be suggested by Telegraph Co. v. Mellon, 100 Tenn., 429 (1898).
} 
It is, indeed, the artificiality of this distinction that seems to me to furnish support to the view that it is an erroneous construction of the commerce clause, that the power to regulate conferred upon Congress thereby is, in any case, that is to say, in the absence of exercise thereof, exclusive of exercise of the power of regulation under the authority of a State. I submit that this is unjustifiable according to established rules of construction. In this view, the power of Congress is merely concurrent, there being reserved to the States the power to regulate in any case otherwise within their jurisdiction, so that to such commerce may be applied indifferently rules based on State legislation and common law rules. But $I$ forbear to further discuss what seems to be a purely academic point.

The existence of the distinction in question seems to have been established in Western Union Tel. Co. v. Call Publishing Co., where a State court was held to have acted rightly in allowing relief on account of discrimination in commerce within the scope of the commerce clause, that is to say, in charges for telegraphic messages sent between points in different States. It was said by Brewer, J., delivering the opinion of a unanimous court: "Can it be that the great multitude of interstate commercial transactions are freed from the burdens created by the common law, . . . and are subject to no rule except that to be found in the statutes of Congress? We are clearly of opinion that this cannot be so, and that the principles of the common law are operative upon all interstate commercial transactions except so far as they are modified by congressional enactment."

This decision was rendered less than eight years before that in Missouri Pacific Ry. Co. v. Larabee Mills, where likewise was presented for consideration the action of a State court in granting relief on account of discrimination in commerce within the scope of the commerce clause, that is to say, with reference to the delivery of cars used in such commerce. If the point involved was not settled in Western Union Tel. Co. v. Call Publishing Co., it would seem to have been highly appropriate to consider the effect of that decision. But, so far as appears from the report, it was considered by neither court nor counsel. Instead of applying the clearly defined rule that "the principles of the common law are operative upon all interstate commercial transactions," etc., the court harked back to the well-established, though as it seems

5 I8r U. S., 92 (I90r). 
to me, the here irrelevant distinction between "matters national" and "matters of local interest," the latter, but not the former, being subject to regulation under State authority in the absence of regulation by Congress. ${ }^{\circ}$ The court, having declared the case not to "rest upon any distinction between interstate commerce and that wholly within the State," said:

"The authority of the State in merely incidental matters remains undisturbed." And there was repudiated the suggestion that "the control of Congress over interstate commerce and a delegation of that control to a commission necessarily withiraws from the State all power in respect to regulations of a local character." It being added: "Until specific action by Congress or the commission the control of the State over these incidental matters remains undisturbed." Nevertheless it was also recognized that common law instead of statutory rules were applicable, it being said: "Here is presented . . . the question of the power of the State to prevent discrimination between shippers and the common law duty resting upon a carrier was enforced. This common law duty, the State, in a case like the present, may, at least in the absence of Congressional action, compel a carrier to discharge."

It is proper to add, however, that the court seems to have reached the same ultimate conclusion as if the rule established in Western Union Tel. Co.v. Calı Publishing Co. had been recognized as applicable. But, however it may be as to the majority opinion, the error that I have pointed out seems clearly manifest in the dissenting opinion that expressed the views of two, if not three members of the court. For such dissent was expressly based on the ground that "the judgment of the court below directly regulated interstate commerce." As we have seen, such judgment was by way of enforcement of a "common law duty," but the writer of the dissenting opinion was, so far as appears therefrom, unconscious of any distinction between regulation under the authority of a State statute and regulation by virtue of application of a common law rule.

This distinction seems also to have been overlooked by the court in Pennsylzania $R$. R. Co. v. Hughes, ${ }^{7}$ where, in giving

6 This distinction, annunciated in Cooley $v$. Port Warders, 12 How., 299, 319 (Dec. 7, I85I), has been frequently reiterated by the Supreme Court. See for instance, Brown i. Houston, II4 U. S., 622, 630 (1885).

7 IgI U. S., 477 (1903). 
effect to the common law rule recognized in a State court (though contrary to that recognized in the Federal courts), denying the right of a carrier to limit its liability for negligence, there was applied as "virtually decisive," Chicago, Milcraukee \& St. Paul Ry. Co. v. Solar. ${ }^{8}$ But that was a case of giving effect to a State statute denying such right of a carrier. On this point the court (in Pennsylvania R. R. Co. v. Hughes) said: "We can see no difference in the application of the principle, based upon the manner in which the State requires this degree of care and responsibility, whether enacted into a statute or resulting from the rules of laze enforced in the State courts." In view of what I have already said, it scarcely needs adding that, in the view herein taken, it was the rule declared in Western Union Tel. Co. $v$. Call Publishing Co., that should have been applied instead of that in Chicago, Milwankee \& St. Paul Ry. Co. v. Solar.

Frederick H. Cooke.

${ }^{8}$ I69 N. Y., I33 (1898). 